\title{
Research on Technical Solutions of Increasing Heating Capacity for 300MW Class Units
}

\author{
Xinjun Zhou ${ }^{1, \text { a }}$, Meng Zhou ${ }^{2, b}$ \\ ${ }^{1}$ North China Electric Power University, Baoding 071003, China \\ ${ }^{2}$ Hebei Electric Power Design \& Research Institute, Shijiazhuang 050000, China \\ azhouxinjun2005@163.com, bhoumeng1118@163.com
} Keywords: condensing-back pressure type unit, waste heat recovery plan with heat pump,
high-back-pressure heat supply.

\begin{abstract}
In order to solve the structural contradiction between heat supply and heat demand in three-north-district, this paper puts forward the solutions of increasing the capacity of heat supply: condensing-back pressure type unit plan, waste heat recovery plan with heat pump, high-back-pressure heat supply plan, and analyzes these three solutions in comparison through such technical features as, investment increasing, heat supply ability, etc.
\end{abstract}

\section{Introduction}

The winter heating mainly relied on 300MW class units in three-north-district. In recent years, because our country has put forward higher requirements for environmental emissions, the development of 300MW class units has been greatly restricted in three-north-district, especially in Hebei Province. At the same time, the regional economy is still growing, and urban population is further increasing, which has leaded to a winter heating huge imbalance of supply and demand.

Increasing the heating capacity of 300MW class units is the effective method, which can solve the structural contradiction between heat supply and heat demand. In order to increase the heating capacity of unit, this paper proposes three technical solutions, and compares their advantages, disadvantages and the economy as a reference for the relevant technical officers.

\section{Theoretical Analysis}

For the moment, the 300MW class units achieve heat supply by extracting the exhaust steam in medium pressure cylinder. For $300 \mathrm{MW}$ class units, the maximum amount of steam extraction is between $500 \mathrm{t} / \mathrm{h}$ and $600 \mathrm{t} / \mathrm{h}$. Under normal circumstances, the medium pressure cylinder flows $100 \sim 150 \mathrm{t} / \mathrm{h}$ to low pressure cylinder at least, in order to maintain air cooling in the low pressure cylinder. The 100 150t/h of steam just does part of the power in the low pressure cylinder, but when it is discharged from the low pressure cylinder, there are still a lot of latent heat being lost. The power consumption rate of turbo generator in the heating condition is

$$
q=\frac{W_{\mathrm{t}}\left(H_{\mathrm{t}}-H_{\mathrm{f}}\right)+W_{\mathrm{r}}\left(\Delta H_{\mathrm{r}}\right)-W_{\mathrm{cn}}\left(H_{\mathrm{cn}}-H_{\mathrm{s}}\right)}{k W_{\mathrm{g}}-\sum k W_{\mathrm{i}}}
$$

Where: $W_{\mathrm{t}}$ is the main stream flow $(\mathrm{kg} / \mathrm{h}) ; W_{\mathrm{r}}$ is the reheat steam flow $(\mathrm{kg} / \mathrm{h}) ; W_{\mathrm{cn}}$ is the heating extraction flow $(\mathrm{kg} / \mathrm{h}) ; H_{\mathrm{t}}$ is the main steam enthalpy of the main valve entrance $(\mathrm{kJ} / \mathrm{kg}) ; \Delta H_{\mathrm{r}}$ is the steam enthalpy difference by repeaters $(\mathrm{kJ} / \mathrm{kg}) ; H_{\mathrm{f}}$ is the feed water enthalpy finally $(\mathrm{kJ} / \mathrm{kg}) ; H_{\mathrm{cn}}$ is the extraction enthalpy of heating $(\mathrm{kJ} / \mathrm{kg}) ; H_{\mathrm{s}}$ is the hydrophobic enthalpy of heating extraction $(\mathrm{kJ} / \mathrm{kg}) ; k W_{\mathrm{g}}$ is the output power of the terminal generator( $\left.\mathrm{kw}\right) ; \sum k W_{\mathrm{i}}$ is the consumed power when using a static excitation, the main oil pump.

By increasing the extraction amount of heating steam, it can significantly reduce the heat rate of class units and improve the operation economy. According to calculations, if the $150 \mathrm{t} / \mathrm{h}$ exhaust of low pressure cylinder is used for heating, it will increase 300 to 400 million square meters of heating area. The focus of this study is that by taking advantage of latent heat of vaporization from the 
exhaust steam of low pressure cylinder, it can increase heating capacity of class units and improve economy.

\section{Technical Solutions}

Condensing-back Pressure Type Unit Plan. For the moment, technology of the 3S clutch has been very mature. For example, “Jinling” power plant, “Shidongkou” power plant and gas turbine project in Chongqing are used the $3 \mathrm{~S}$ clutch. We take the conventional 350MW supercritical steam turbine as the female, and connect the shaft of the low pressure cylinder with the high pressure cylinder, so that the low pressure cylinder can be splitting and parallel online.

(1) In heating season, low pressure cylinder disengages with high pressure cylinder by the 3S clutch; the valve of intermediate pressure cylinder exhaust is closed; the low pressure cylinder splits; steam turbine runs by back pressure; a single steam turbine exhaust steam maximum amount is $700-750 \mathrm{t} / \mathrm{h}$; rated exhaust pressure is $0.25-0.4 \mathrm{MPa}$.

(2) When amount of heating steam is less than $600 \mathrm{t} / \mathrm{h}$, connecting the $3 \mathrm{~S}$ clutch to generator(or the high pressure cylinder) in running state, partly opening the exhaust valve of the intermediate pressure cylinder, and the steam turbine turning into the operation extraction and condensing, and heating steam is adjusted by the exhaust valve of intermediate pressure cylinder.

(3) In non-heating conditions, the 3S clutch connected the low pressure cylinder to the shaft of high pressure cylinder, and fully opening the pressure cylinder exhaust valve, and then operating pure condensing steam turbine.

The condensing-back pressure type unit plan should make a big adjustment for heating unit structure of a conventional 300MW turbine class unit, heating systems and main plant layout, which is more complex. The demonstration of "Yuhua" two installed program heat and power plant [1] and the demonstration of "Luhua" two installed program heat and power plant [2] has been completed in Shijiazhuang.

Waste Heat Recovery Plan with Heat Pump. Absorption heat pump driven by high temperature heat source, the heat of low temperature heat source is increase to medium temperature, thereby improving energy use efficiency of the system. Lithium bromide absorption heat pump includes evaporator, absorber, condenser, generators, heat exchanger, pumps shielding and other accessories, as shown in Fig.1.
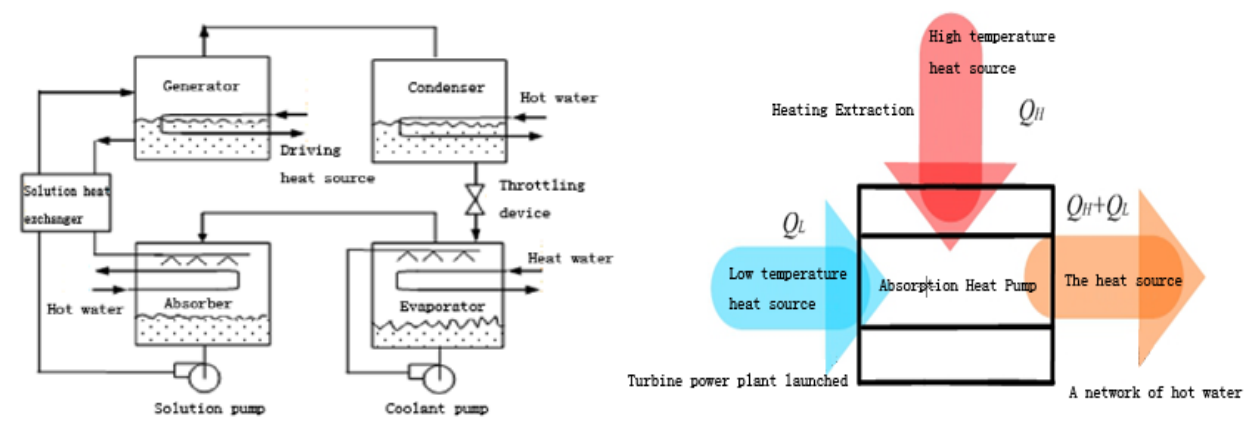

Fig.1 Schematic of absorption heat pump Fig.2 Schematic of steam-driven absorption heat pump

Steam is used as the driving heat source, and release heat $Q_{\mathrm{g}}$ in the generator which can be used to heat lithium bromide dilute solution and produce refrigerant vapor. Refrigerant vapor enters the condenser and release the condensation heat $Q_{c}$ which can be used to heat hot water flow through the heat transfer tube of the condenser. Refrigerant vapor is condensed into liquid and throttled into the evaporator. Refrigerant water is sprayed onto the surface of the evaporator heat transfer tube through coolant pump, and absorbs the heat $Q_{\mathrm{e}}$ of low-temperature heat source water flow through the transfer tube heat. The heat source water flow out unit after lowering the temperature of it, the refrigerant water is vaporized into steam after absorbing heat and the vaporized steam enters the absorber. lithium bromide solution which was concentrated in the generator spray after return the absorber, and release heat $Q_{\mathrm{a}}$ after absorbing refrigerant vapor come from the evaporator, which can be used to heat 
hot water flows heat transfer tube of the absorber; hot water flow through the absorber, condenser is heated, and supply the heat $Q$ to the heat user, it can be expressed by $Q=Q_{\mathrm{e}}+Q_{\mathrm{a}}=Q_{\mathrm{g}}+Q_{\mathrm{c}}$, obviously.

For power plant waste heat recovery absorption heat pump, the driving heat source is turbine extraction steam, low-heat source is turbine exhaust steam (air-cooled units) or circulating water before entering the cooling tower (wet units), heated hot water (the medium heat source) is central heating hot net backwater. As shown in Fig.2, the system uses turbine extraction steam as driving heat source $Q_{\mathrm{H}}$, produces refrigeration effect, recover waste heat $Q_{\mathrm{L}}$, and heat the heating network backwater. Useful heat (thermal network heating value) is the sum of steam heat consumption and recycling of waste heat of the exhaust steam $Q_{\mathrm{H}}+Q_{\mathrm{L}}$. Coefficient of performance of heat pump (COP) is defined as the ratio of useful heat and steam heat consumption, $C O P=\left(Q_{H}+Q_{L}\right) / Q_{L}$. If the single-effect absorption heat pump COP $=1.7$, it mean that the system consume one part turbine heating extraction steam heat, recovery 0.7 part exhaust steam heat, and supply 1.7 part heat for the heating network. Thus, the heat supply of absorption heat pump is always greater than the heat consumption of high-grade heat source, it have significant energy-saving advantages.

Table 1 Comparison of the increased heating capacity between three plans

\begin{tabular}{|c|c|c|c|}
\hline $\begin{array}{l}\text { Comparison } \\
\text { Project }\end{array}$ & $\begin{array}{l}\text { Condensing-back pressure } \\
\text { type unit plan }\end{array}$ & $\begin{array}{l}\text { Waste heat recovery plan } \\
\text { with heat pump }\end{array}$ & $\begin{array}{l}\text { High back pressure heat supply } \\
\text { plan }\end{array}$ \\
\hline $\begin{array}{l}\text { Increased } \\
\text { investment } \\
\text { relative to } \\
\text { conventional } \\
\text { 300MW units } \\
\end{array}$ & $\begin{array}{l}\text { Increased investment in less } \\
\text { than } 40 \text { million. }\end{array}$ & $\begin{array}{l}\text { Increased investment in } \\
\text { more than } 100 \text { million, a } \\
\text { relatively higher }\end{array}$ & $\begin{array}{l}\text { Increased investment in less than } 10 \\
\text { million, very little }\end{array}$ \\
\hline $\begin{array}{l}\text { The degree of } \\
\text { technical } \\
\text { complexity }\end{array}$ & $\begin{array}{l}\text { Involves 300MW unit } \\
\text { system, and a substantial } \\
\text { adjustment on the control } \\
\text { and arrangement, technical is } \\
\text { complex. }\end{array}$ & $\begin{array}{l}\text { Does not affect the unit } \\
\text { itself. Absorption heat pump } \\
\text { should pay attention to the } \\
\text { matching of high } \\
\text { temperature and low } \\
\text { temperature heat source, } \\
\text { technology is more complex }\end{array}$ & $\begin{array}{l}\text { Only relates to a high pressure } \\
\text { condenser and a part of the pipeline } \\
\text { and the valve,technology is simple. }\end{array}$ \\
\hline $\begin{array}{l}\text { Technical } \\
\text { reliability }\end{array}$ & $\begin{array}{l}\text { There are some production } \\
\text { performance in gas turbine } \\
\text { projects, but has not yet the } \\
\text { performance on the thermal } \\
\text { power projects }\end{array}$ & $\begin{array}{l}\text { Domestic production } \\
\text { performance, technology is } \\
\text { mature and reliable }\end{array}$ & $\begin{array}{l}\text { The performance of domestic } \\
\text { operation. But for the wet cooling } \\
\text { unit, must replace the last stage } \\
\text { blade of steam turbine for } 2 \text { times } \\
\text { each year, it has a greater impact on } \\
\text { the life and reliability of the turbine }\end{array}$ \\
\hline $\begin{array}{l}\text { Heating capacity } \\
\text { of the unit }\end{array}$ & $\begin{array}{l}\text { The heating capacity is } \\
\text { largest. 2X300MW level } \\
\text { units can bear about } \\
20000000 \text { square meters of } \\
\text { heating area }\end{array}$ & $\begin{array}{l}\text { By the pump parameter } \\
\text { limits, the heating capacity is } \\
\text { slightly lower than the } \\
\text { scheme } 1 . \\
\text { Heating ability of air cooling } \\
\text { unit is higher than wet } \\
\text { cooling unit }\end{array}$ & $\begin{array}{l}\text { For air cooling units, heating } \\
\text { capacity is equal to scheme } 2 . \\
\text { For wet units, heating ability is } \\
\text { higher than scheme } 2 \text {. }\end{array}$ \\
\hline $\begin{array}{l}\text { Heat Economy of } \\
\text { Heating period } \\
\text { unit }\end{array}$ & $\begin{array}{l}\text { During the period of } \\
\text { heating, units can be run as a } \\
\text { back pressure turbine, the } \\
\text { economy is good }\end{array}$ & $\begin{array}{l}\text { In the case that unit back } \\
\text { pressure does not } \\
\text { significantly improve, units } \\
\text { recover the waste heat of low } \\
\text { pressure cylinder exhaust } \\
\text { steam waste heat, the } \\
\text { economy is good }\end{array}$ & $\begin{array}{l}\text { During the period of heating, units } \\
\text { can be run as a back pressure } \\
\text { turbine, the economy is good }\end{array}$ \\
\hline
\end{tabular}

High-back-pressure Heat Supply Plan. By comparing with the previous two scheme and high back pressure heating scheme, we can find technology of high back pressure heating scheme is relatively simple:

(1) In Fig.3, the wet cooling unit can increase back pressure of turbine exhaust steam to improve the heat transfer capability by replacing the last stage turbine blades. The cooling medium of the condenser is no longer circulating cooling water, but the return water of the heat supplying network. Heating network backwater absorb the latent heat of vaporization of turbine exhaust steam after 
entering the condenser, for the primary heating; then entering the network of hot water heater, and absorb turbine heating extraction steam heat for secondary heating.

(2) For the air cooling unit, the heating scheme is similar with the wet cooling unit, heating supply network backwater is also through a two-stage heating. But since it does not have condenser, thus it need to add high Pressure Condenser. For heating stage, air cooling unit use butterfly valve to isolate air cooling island, turbine exhaust steam is introduced into the high pressure condenser.

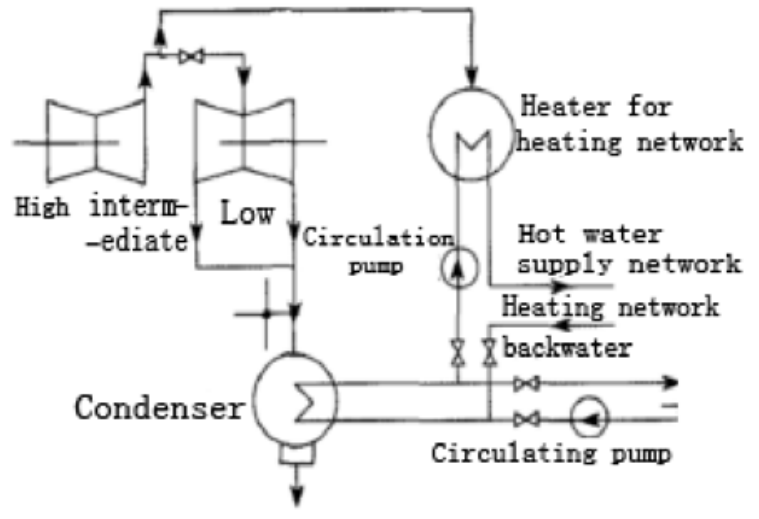

Fig.3 Schematic of wet unit’s high back pressure scheme

\section{Scenario Comparison}

In recent years, the author have studied the increased heating capacity for multiple units of Hebei Province. Based on these findings, these three scheme presented in this paper are compared in Table 1.

\section{Summary}

(1)This paper presents three schemes, which is feasible and reliable for the technology. Compared with the conventional units, these can increase unit heating capacity significantly and realize energy saving and consumption reduction at the same time.

(2)Condensing-back pressure type unit plan has the advantages of less investment, heating capacity, and good economy, it should be recommended in new power plants of the three northern regions.

(3)Heat pump heat recovery project and high back pressure heating plan is suitable for the case that temperature of outside network backwater is low. Moreover, the operation parameters of outside network have a greater impact on the economy of the two schemes. Therefore, the two proposed scheme are mainly used for the reconstruction of the existing unit, and the recommended scheme are obtained after conducting technical and economic comparison according to the specific needs of users and external conditions.

\section{References}

[1] Yuan Sun, Meng Zhou, Fuhua Yan, The demonstration of "Luhua" two installed program heat and power plant, Hebei Electric Power Design and Reseach Institute, Shijiazhuang, 2010.

[2] Meng Zhou, Fuhua Yan, The demonstration of "Yuhua” two installed program heat and power plant, Hebei Electric Power Design and Reseach Institute, Shijiazhuang, 2010.

[3] Jianren He, Qiguo Yang, Damao Xu, New Type Steam Turbine for Cogeneration, Engineering Sciences. 28 (2010) 81-84.

[4] Jianming Shao, Pengshuai Chen, Yong Zhou, An application of double-rotor interchange technology in the retrofit for a high back pressure heat supply system with 300MW condensing turbine, Energy Research and Information. 30 (2014) 100-103. 